JOURNAL OF SECURITY AND SUSTAINABILITY ISSUES ISSN 2029-7017 print/ISSN 2029-7025 online 2020 June Volume 9 Number 4 https://doi.org/10.9770/jssi.2020.9.4(30)

Scopus

\title{
FINANCIAL SECURITY MANAGEMENT OF ENTERPRISES OPERATING IN THE DEFENSE INDUSTRY
}

\author{
Oleksandr Sydorov ${ }^{1}$, Serhii Tarasov ${ }^{2}$, Nelli Tsybulnyk ${ }^{3}$, Tetiana Tsybulnyk ${ }^{4}$, Anatolii Rusetskyi ${ }^{5}$

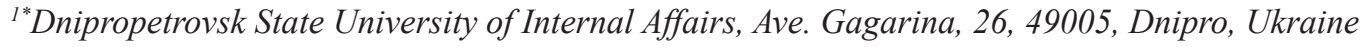 \\ ${ }^{2}$ Central Research Institute of the Armed Forces of Ukraine, 28 b Povitroflotsky Ave., Kyiv-49, 03049, Ukraine; \\ ${ }^{3}$ Kharkiv National University of Internal Affairs, Lviv Landau avenue, 27, Kharkiv, 61000, Ukraine; \\ ${ }^{4}$ Novobavarskyi District of Kharkiv City Council, Poltavsky Shlyakh Street, 11, Kharkiv, 61000, Ukraine; \\ ${ }^{5}$ M.S. Bokarius Kharkiv Research Institute of Forensic Examinations, Zolochevskaya street, 8a, Kharkov, 61000, Ukraine
}

E-mail: ${ }^{1 *}$ koaduep@gmail.com (Corresponding author)

Received 19 October 2019; accepted 15 May 2020; published 30 June 2020

\begin{abstract}
The article investigates the specifics of the military-industrial complex functioning in Ukraine. Theoretical analysis has shown that the development of the country's defense industry and the state of enterprise's financial security within this industry have a dual impact on various components of the national security system: is a realization tool of the national interests, which in turn creates opportunities for its strengthening, and it can also be a source of threats to the state's economic security by its components due to the accumulation of internal negative elements on enterprises (insufficient development and low level of military products competitiveness, obsolescence of fixed assets at enterprises, etc), as well as due to the low ability of enterprises to respond adequately to the challenges arising from changes in external conditions and factors (disruption of sustainable cooperation, increased competition between different military products in domestic and foreign markets, etc). The activity legal framework, legal status and structure of the state concern "Ukroboronprom" have been defined. The strategic growth priorities of defense industry of Ukraine have been cleared up. The financial security of enterprises operating in the defense industry can be ensured not only by using passive mechanisms to resist internal and external destructive factors, but also by mechanisms of efficient interaction with the environment. This in turn allows the company to avoid the need to invest capital in sources of raw materials, production or creation of distribution channels. Access to certain technologies or knowledge, the advantages of narrow specialization and the possibility of increasing consumer value, these all are important reasons for establishing strategic cooperation between different companies.
\end{abstract}

Keywords: national security, financial security, national interests, product competitiveness, defense-industrial complex.

Reference to this paper should be made as follows: Sydorov, O., Tarasov, S., Tsybulnyk, N., Tsybulnyk, T., Rusetskyi, A. 2020. Financial security management of enterprises operating in the defense industry. Journal of Security and Sustainability Issues 9(4), 1483-1495. https://doi.org/10.9770/jssi.2020.9.4(30)

JEL Classifications: F35; F42

\section{Introduction}

The significance of financial security issue as a component of economic security of defense industry enterprises can be proved by the fact that financial security has an exclusive role in ensuring sustainable development and is a prerequisite for achieving and maintaining sustainable financial performance of the enterprise. World experience has shown that this contributes not only to the formation of the country's defense industry, but also to economic growth, improving its technological level, manufacturing development of dual-use goods, as well as industries oriented on the military services.

The remilitarization of the economy reveals significant opportunities for Ukraine, due to the increasement in the manufacturing of military goods and the expansion of the corresponding export potential. In the future, the 
development of military technologies in the enterprises of the defense industry and their usage for the benefit of the civil sector can ensure economic growth and create positive macroeconomic, scientific and technological, financial effects in the country.

The need to adapt to radical changes in the orientation of domestic production and export-import policy since 2014 has led to the usage of anti-crisis management tools of the defense industry and situational solutions to problems related to its development and functioning.

The development of a global market system requires the national economy of a country to integrate into the world economic space by creating stable goods/money relationships. In a market economy, competitiveness holds an important place among the key categories. At that, the level of competitiveness is determined not only by the success or failure in the activity of a certain economic entity, but also, ultimately, the positioning of the country itself in today world market.

At the same time, in the conditions of modern integration into the world economic space, the possibility for many external challenges and threats to influence the economic development of the country is not ruled out. Therefore, special attention is paid to solving the issues of ensuring the protection of national interests of manufacturers of products and the whole society, national security of the state as a whole. An important component of a national security and defense strategy in many industrialized countries is the presence of a powerful and modern defense industrial complex capable of functioning even in the event of threats to national security and possible crisis situations.

The development and maintenance of the scientific, technical, technological and intellectual potential of the defense industrial complex of Ukraine requires the integration of national production processes into a complex global system through technological changes and modernization of industry in accordance with world standards. At the same time, today in Ukraine there appears relevant to solve the issues regarding the improvement of the efficiency of use of production, scientific, experimental capabilities and material and technical base of the defense industry; to attract foreign investments in the defense industrial complex; to provide favorable conditions for expansion of the markets of defense products taking into account the national security interests of the country.

\section{Literature Survey}

The specifics of the formation, operation, current state and horizons of development of the defense industrial complex (DIC) have repeatedly aroused scientific interest regarding the study of these issues. In the context of the subject under study, we consider it necessary to consider scientific approaches to defining the essence of the concept of DIC.

While studying the state and the horizons of development of the defense industry of Ukraine in the system of formation of national sovereignty, Kamianetska (2015) defines DIC as a sector of economy intended for the development and production of defense products. The scientist argues that DIC is in fact the foundation of the country security and defense, so maintaining a high level of its development for many developed countries is one of the priority military and economic objectives of national policy in the system of providing the sovereignty of the state.

According to Avanesova et al. (2018), DIC is a generator of advanced scientific, technical, technological advances and developments. According to scientists, this provides the opportunity to create not only high-tech equipment, but also high-tech conversion products.

Momot et al. (2015) understand by the term DIC a group of enterprises, institutions and organizations of industry and science that develop, produce, modernize and dispose of military products, perform services in the interests of defense for equipping and provision of material needs of security and defense forces, as well as supply military and dual use goods, provide military services at the time of military-technical cooperation activities of the country with foreign countries. 
According to Potomkina (2018), DIC is an integrated system that includes enterprises, institutions, organizations, which are considered:

(1) on the one hand - as facilities (engaged in the development and production of weapons, ammunition, military equipment, special accessories to them);

(2) on the other hand - as economic entities subordinated to organizational-economic authorities in accordance with the powers conferred on them by law, which are involved in the placement, execution of the state defense order, have the functions to regulate and control the activity of the economic entities in the area of DIC, in respect of which they exercise regulatory, management, administrative, and control functions.

Kravchenko V. (2019) states that the notion of "defense industrial complex" used in Ukraine in other states is known as "military industrial complex". With that, the author defines the military industrial complex as a group of defense enterprises of all forms of property, research, design and testing organizations, training grounds, institutions and organizations, top military leadership, and political elite, which provide military and national security of the country. The DIC of Ukraine provides the execution of the state defense order, and also carries out deliveries of weapons for export.

Indeed, if we refer to foreign scientific literature on defense industry research, the term "military industrial complex" (MIC) is generally used.

Thus, in particular, Weber (2020) defines MIC as a network of persons and institutions engaged in the production of weapons and military technologies. Usually, the MIC of a country tries to mobilize political support to continue or increase military spending by the national government.

According to Qureshi (2018), the MIC should be understood as events, processes, a structure and a multitude of agreements that take place between the military and the industry of the country concerned. The scientist states that there is a structural network between the armed forces and the political-economic complex where both regulated and intensive flows of technologies, finances, services and products take place.

The scientists Nzeribe \& Imam (2018) define the MIC as an informal alliance between the military and the industry that supply weapons and is also viewed as a vested interest that influences the public policy and thought. It is important to note that such a relationship between the government and defense-oriented corporations is a driving factor as both parties benefit by it: one party receives weapons and the other party pays for its supply.

Insufficient scientific research of these issues necessitates the solution of the scientific task, which is to ensure the financial security of defense enterprises, taking into account the threats and opportunities for the development of their interaction with the environment on the basis of the development of conceptual, methodological and applied components.

\section{Methods}

The following methods of scientific cognition were used in the work: statistical analysis, comparison, economic-mathematical and graphic methods - when determining the conditions and factors that affect the financial security of enterprises involved in the defense industry of Ukraine, as well as systematization and statistical analysis - during the substantiation of scientific and methodological approaches to the application of the value concept of pricing for military products and its dual usage by defense industry enterprises.

With the purpose of studying the specifics of operation of the DIC in the leading countries of the world and in Ukraine, in particular, as regard the activities of corporations in the structure of the DIC and research institutions in the area of defense industry, and the interpretation of the basic principles of strategic planning documents, etc., a complex of general scientific and special legal methods. They are: dialectical, epistemological, formal legal and system-structural methods. 
The dialectical method was used to define the concepts of "defense industrial complex" and "military industrial complex" by studying the scientific approaches to interpreting their essence.

The epistemological method of research allowed to find out the specifics of PESCO activities in the area of defense cooperation between the EU member states, as well as the essence of the main principles of the implementation of the Project of Property Policy of the state concern "Ukroboronprom".

By using the formal legal method, there was explained the essence of some provisions of the current regulatory legal acts, which define the powers of the Ministry of Defense of Ukraine, the Ministry for Development of Economy, Trade and Agriculture of Ukraine in the field of defense and national security of the state; the legal status and structure of the state concern "Ukroboronprom"; strategic growth priorities of the DIC of Ukraine and so on.

As a result of the conducted study on the specifics of operation of the DIC in the leading countries of the world and in Ukraine and using the system-structural method, the obtained results were systematized according to the following criteria: country, main corporations in the structure of DIC; research institutions in the area of defense industry; basic strategic planning documents.

The information basis of the work consists of: laws of Ukraine, regulations of the Ukrainian Cabinet of Ministers, mandates of the President, official documents of public administration authorities, statistical data provided by the State Statistics Service of Ukraine, defense enterprises, materials of analytical institutions, scientific works of domestic and foreign scientists in the defense sphere and economic security of the state, as well as the results of expert surveys, materials from the Internet, the results of author's personal researches.

\section{Results}

In modern economic conditions, regardless of the form of ownership and organizational and legal form of management, the activities of enterprises are subject to constant risks and threats, which are due to increasing influence of external and internal factors on their functioning. The constant increase in business risk can lead to a significant reduction in the level of financial condition of the enterprise, and as a consequence - to bankruptcy, and therefore requires each business entity to develop and implement its own special financial security system.

Defense companies involved into the production of military products can not exist and develop without some certainty in the development of these products for both domestic needs and for the foreign arms market. This fact is a necessary condition for ensuring the rationality of the military-technical policy of the state related to the development of the armament system of the armed forces, other military institutions of the state, scientific, technical and production-technological base of the defense industry, as well as to the improvement of the military-technical cooperation with foreign countries.

In 1966 an independent international institute was established to conduct research in the fields of conflicts, arms, arms control and disarmament - Stockholm International Peace Research Institute (SIPRI). SIPRI provides indicators, analysis and recommendations based on open sources to policy makers, researchers, the media and the public concerned. Based in Stockholm, SIPRI is regularly ranked among the most respected think tanks around the world.

SIPRI monitors, measures and analyzes international arms transfers and is one of the world's leading centers of research in this field. In particular, within the framework of its activities SIPRI conducts studies into arms transfers to or from certain regions, subregions, states or non-state actors focused both on enhancing the fundamental understanding of the impact of arms transfers and supporting policy development and implementation. An important purpose of SIPRI studies is to promote the improvement of transparency as a method of providing responsible international arms transfers, thereby helping to prevent violent conflicts, reduce tensions, prevent potentially destabilizing accumulation of weapons and stand against the misallocation of limited resources. According to the recent published data on the official website of SIPRI, the top ten exporters of defense products 
are: (1) USA - 59\%, (2) Russia - 8,6\%; (3) United Kingdom - 8,4\%; (4) France - 5,5\%; (5) Italy - 2,8\%; (6) Japan - 2,4\%; (7) Israel- 2,1\%; (8) Germany - 2\%; (9) India - 1,4\%; (10) South Korea - 1,2\% (Arms production graphics (SIPRI Top 100)).

Nowadays, Ukraine demonstrates positive dynamics in the development of the defense industry. During the period from 2015 to 2018, funding for the development, production, repair and modernization of armaments and military equipment was significantly increased, international cooperation was established through defense institutions, and sustainable development of the defense industry was identified as one of the priorities in strategic and program documents, and systemic restructuring of the Ukrainian defense industry is recognized as an indicator of its achievement.

At the same time, there is a major (primary) objective contradiction between the development strategy of enterprises, including their operating activities, and the possibilities for its financial support. The impact of this contradiction is the main driver of the enterprise`s financial security.

Features of the activities of enterprises involved in the defense industry and, accordingly, certain risks and threats to their financial security, affect the nature of their financial activities. The main comprehensive characteristic of the enterprise's economic activity is its financial condition, which characterizes competitiveness, potential in business cooperation, as well as assesses the realization of economic interests of the enterprise and its partners in financial and production terms.

And on the other hand, in exchange for subsidies, MIC enterprises are expected to return their savings to the state through reduced prices for their products in the future (Usachenko, 2019).

In the conditions of the current integration into the world economic space, strategic goals to ensure the protection of national interests of manufacturers of products and the whole society, national security of the state as a whole are a priority. National security and defense protection is one of the priority, strategically significant areas for the country development, its positioning in the world community (Reznik et al., 2020).

In Ukraine, the documents of the strategic planning for national security and defense protection were presented by the National Security Strategy of Ukraine 2015; Cybersecurity Strategy of Ukraine 2016; Strategy for the Development of the Defense Industrial Complex of Ukraine for the Period until 2028.

The DIC of Ukraine is represented by the state concern "Ukroboronprom" created in 2010. The purpose of creation of "Ukroboronprom" was defined as improving the efficiency of operation of state-owned enterprises that carry out economic activity in the area of design, production, implementation, maintenance, modernization and disposal of arms, military and special equipment and ammunition and participate in military-technical cooperation with foreign countries. According to the existing legislation, as of October 4, 2018, 125 state-owned enterprises were included in the state concern "Ukroboronprom". It is important to note that, in addition to state-owned enterprises, "Ukroboronprom" includes 9 joint stock companies. Since 2013, the enterprises of the state concern have been grouped into 5 main divisions, namely: (1) aircraft industry and aircraft maintenance; (2) precision weaponry and munition; (3) armored vehicles, automotive equipment, engineering and special equipment; (4) shipbuilding and marine facilities; (5) radar, radio communications and air defense systems (ADS) (Resolution of the Cabinet of Ministers of Ukraine № 1221, 2010).

The activity of the state concern "Ukroboronprom" is regulated by the provisions of the Statute approved by the resolution of the Cabinet of Ministers of Ukraine "Some issues of the state concern Ukroboronprom" of 2011. The activities of "Ukroboronprom" are focused on providing the efficient operation and management of public sector economic entities that carry out economic activities in the area of design, production, implementation, maintenance, modernization and disposal of arms, military and special equipment and ammunition and participate in military-technical cooperation with foreign countries. The structure of governing bodies of "Ukroboronprom" includes: 
(1) the Supervisory Board as the supreme governing body that protects the interests of the state, controls and regulates the activities of other governing bodies of the concern;

(2) the Board of Directors as the collegial governing body comprising CEO (Head of the Board of Directors) and his deputies, as well as the representatives of the concern participants;

(3) CEO (Resolution of the Cabinet of Ministers of Ukraine № 849, 2011).

In 2018, the Strategy for Development of the Defense Industrial Complex of Ukraine for the period up to 2028 was developed and approved by the resolution of the Cabinet of Ministers of Ukraine. The development of the Strategy was conditioned by the need for the state institutions of Ukraine to review the role of the DIC in the context of neutralizing internal and external threats to national security, as well as intensifying the economic growth of the state. The Strategy is the basis for developing new and revising existing regulations (including state target programs) in the area of development and operation of the DIC. The strategy defines the long-term priorities of the state military-industrial policy, as well as the directions of implementation of the state target programs of reforms and development of the DIC in the medium term (Strategy for development of the defenseindustrial complex of Ukraine for the period up to 2028, 2018).

The "Ukroboronprom" reform strategy aims to integrate the Ukrainian DIC into the global high-tech market. The reforms are focused on close international cooperation within the framework of innovative tendencies and provides for simultaneous work in the legal, technological and industrial directions. An important component of effective reforms is improving the legal framework and bring up legislation to world-class standards (The official website of Ukroboronprom).

Among the recent reform events, special attention is required by the draft ownership policy of the state concern "Ukroboronprom" - the fundamental document that defines the purpose of existence of the concern in state ownership, key objectives, financial and non-financial performance indicators. This darft document was developed by experts of the Ministry for Development of Economy, Trade and Agriculture of Ukraine. The proposed version of the ownership policy stipulates that the Concern has a key client and the purpose of existence - to create modern and high-quality arms and military equipment for the defense and security forces of Ukraine, in particular, two ministries - the Ministry of Defense of Ukraine and the Ministry of Internal Affairs of Ukraine.

The ownership policy proposes to assign to the Concern a key role in the field of design, production, implementation, maintenance, modernization and disposal of weaponry, military and special equipment and munition, through the formation of a long-term state defense order for the products of the Concern participants and joint stock companies in respect of which the Concern exercises management authorities of the participatory interests of the state. According to the draft document, as the main directions of activity, it is proposed to define the management of the Concern participants and the participatory interests of the state in the authorized capital of joint stock companies, which are placed under management of "Ukroboronprom".

Central Scientific Research Institute of Armament and Military Equipment of Armed Forces of Ukraine (CSRI AME AF of Ukraine) is the main research institution of the Armed Forces of Ukraine engaged in the study of the problems of military-technical policy in the field of development of weapons and military equipment, which carries out its activity through conducting fundamental, exploratory and applied studies focused on the scientific substantiation of the priority directions of military-technical policy regarding the problems of creation of new weapons, development and modernization, service life extension and disposal of WME, weapons of destruction and munitions, special-purpose vehicles and equipment, prospects of development of WME of the Armed Forces of Ukraine, defense technologies and defense industrial complex, scientific-methodical support for development and implementation of MTP, state target defense programmes of development of WME, state defense order and activities of the international MTC, scientific-technical support for development and modernization, service life extension and disposal of WME, as well as providing the operation of the intellectual property protection system during scientific studies (The official website of the Central Scientific Research Institute of Armament and Military Equipment of Armed Forces of Ukraine). 
Nowadays, Ukraine demonstrates positive dynamics in terms of the defense industry development. During 2015-2018, the amount of funding for the development, production, repair and modernization of armaments and military equipment was significantly increased, as well as international cooperation was established through defense institutions. In the strategic and program documents of the state, the sustainable development of the defense industry was recognized as one of the priority areas, and the systemic restructuring of the Ukrainian defense industry was identified as a way to achieve it.

In modern conditions, a number of external and internal negative conditions and factors significantly affect the financial security of Ukrainian defense industry enterprises, which deepen the contradictions in the practice of Ukrainian defense companies, which in turn complicates their financial security.

The strategic goal of ensuring the financial security of enterprises involved into the defense industry is to ensure the realization of their interests, including using the opportunities provided by the external environment, and the implementation of a preventive response to emerging threats. Instead of passively adapting to external challenges and threats, public sector defense companies should conduct a strategy of actively promoting their own interests, taking into account the interests of other subjects in the environment.

Nowadays, foreign partners have shown a willingness to import military technology. Thus, at the international arms exhibition "Eurosatory-2012" authorized Ukrainian and Thai representatives confirmed the possibility of common production (with transfer of production technologies ownership) of armored personnel carriers model ZE-1 in Thailand. The estimated value of the contractual relationship amounted to more than 110 million dollars. In addition, recently the authorized representatives of our state have declared their readiness to produce armored personnel carriers in common with the representatives from Kazakhstan. According to the estimation of experts, the cost of these contractual relations may be about 50 million USD (http://myfin.net/ukraine/ economy-and-finances-ua/eksport-voennyx-texnologij-komu-eto-vygodno-09125774.html.).

The value of the above-mentioned export agreements, as a rule, consists of the following three components: the value of products manufactured by the exporting country it-self; the value of products manufactured in common by representatives of the exporting state and the importing state; cost of transferred technology (cost of licenses).

The implementation of these projects will have a positive impact on the development of Ukraine's military industry, and the average annual volume of military technology exports is expected to be at least 200 million USD (On approval of the Strategy for the development of the defense-industrial complex of Ukraine for the period up to 2028).

The analysis of the state of Ukrainian exports of military technologies allowed to characterize its main indicators (Table 2).

Table 2. Characteristics of exports of Ukrainian military technologies

\begin{tabular}{|c|l|}
\hline Indicators & \multicolumn{1}{c|}{ Characteristic } \\
\hline Geographical structure & Persian Gulf States, Southeast Asia, CIS and China. \\
\hline Subject structure & $\begin{array}{l}\text { Technologies for the production of aircraft, tanks, armored personnel carriers, warships, } \\
\text { modernization of already exported equipment. }\end{array}$ \\
\hline Average annual amount & About 30 million USD \\
\hline Degree of state control & $\begin{array}{l}\text { Low. Ukraine has lost a significant amount of military technology and, as a result, the possibility of } \\
\text { concluding contracts for the export of products or production technologies due to an insufficiently } \\
\text { effective control system. }\end{array}$ \\
\hline $\begin{array}{c}\text { The degree of export potential } \\
\text { realization of the military } \\
\text { technologies in Ukraine }\end{array}$ & $\begin{array}{l}\text { Does not exceed 25\%. Exports of military technology are unsystematized. One contract is usually } \\
\text { concluded within two or three years. }\end{array}$ \\
\hline
\end{tabular}


The characteristic mentioned above was compiled on the basis of the analysis of previous years. First of all, it should be noted that despite the significant number of negative factors, Ukrainian companies still tried to export military technologies. However, due to the lack of an effective state policy, Ukraine did not fully use its own export potential, which in turn led to a significant decline in the development of Ukrainian military-industrial complex (MIC).

Investigating Ukraine's capabilities in the field of geographical diversification of military technology exports, it should be noted that one of the most promising markets for Ukrainian manufacturers are the markets of military technology (MT) in Asia, the Middle East and South America. Futhermore, in modern conditions, Ukraine also has certain prospects for military-technical cooperation with high-developed countries, primarily with EU and NATO member states.

During 2014-2019, the private sector of the defense industry was actively developing, namely: 69\% of the volume of the state defense order (SDO) in 2018 was performed by private enterprises. У питанні The rearmament of the defense forces has significantly advanced national missile programs and developments, as well as initiated the development of a number of large weapons. A range of local achievements in the field of rearmament and re-equipment of the defense forces have been recorded. However, despite the increase desire of private enterprises to meet the needs of domestic and foreign markets, there are still some bans at the state level, which do not allow to achieve significant progress in this sphere.

Taking into account the significant international restrictions on the import of military goods and technologies to Ukraine, the re-equipment of the Armed Forces and other military formations is carried out mainly at the expense of own production facilities and developments by private and state enterprises. Table 3 presents the volumes of manufactured military products at defense industry enterprises of all forms of ownership in Ukraine in the period 2014-2019.

Table 3. Volumes of manufactured military products in Ukraine at defense industry enterprises of all ownership forms in the period 2014-2019, million UAH

\begin{tabular}{|c|c|c|c|c|c|c|c|c|c|c|c|c|}
\hline \multirow{2}{*}{ Indicator } & \multicolumn{2}{|c|}{2014} & \multicolumn{2}{|c|}{2015} & \multicolumn{2}{|c|}{2016} & \multicolumn{2}{|c|}{2017} & \multicolumn{2}{|c|}{2018} & \multicolumn{2}{|c|}{2019 (1 quarter) } \\
\hline & Amount & $\%$ & Amount & $\%$ & Amount & $\%$ & Amount & $\%$ & Amount & $\%$ & Amount & $\%$ \\
\hline $\begin{array}{l}\text { In general, } \\
\text { including: }\end{array}$ & 9613,4 & 700 & 13619,1 & 700 & 13366,2 & 700 & 16365,9 & 700 & 25489,5 & 700 & 5755,9 & 700 \\
\hline R\&D & 191,9 & 2,0 & 453,5 & 3.33 & 352.2 & 2,64 & 516,6 & 3,16 & 1453,0 & 5,7 & 574,0 & 10.0 \\
\hline $\begin{array}{c}\text { purchase of } \\
\text { defense equipment }\end{array}$ & 1141,1 & 77,9 & 5907,1 & 43,36 & 4920,4 & 36,8 & 5570,7 & 34,0 & 11358,0 & 44,6 & 3228,5 & 56,1 \\
\hline MT utilization & 42,2 & 0,45 & 117,1 & 0,86 & 450,9 & 3,38 & 81,4 & 0,5 & 58,5 & 0,3 & & \\
\hline MT processing & 4,3 & 0,05 & 0,5 & 0,01 & 7,5 & 0,06 & 1,0 & 0,01 & 198,0 & 0,8 & - & - \\
\hline MT Reparation & 2207,0 & 22,9 & 3283,5 & 24,17 & 4740,5 & 35,47 & 5820,6 & 35,6 & 8625,2 & 33,8 & 1953,4 & 33,9 \\
\hline serial products & 6026,8 & 62.7 & 3857,4 & 28,33 & 2894,7 & 21,66 & 4375,6 & 26,7 & 3796,8 & 14,8 & - & - \\
\hline \multicolumn{13}{|c|}{ For reference: } \\
\hline $\begin{array}{l}\text { Number of } \\
\text { contracts }\end{array}$ & 1450 & & 1937 & & 1756 & & 1572 & & 1753 & & - & \\
\hline
\end{tabular}

Source: compiled by the author using the resource http://www.dsecu.gov.ua/control/en/index

The results of the data shown in Table 3 allow us to draw the following conclusions:

- the main shares of financial resources of enterprises are spent on repair and purchase of MBT, while the modern equipment is not produced enough - in 2015 the share of serial production in the total volume of manufactured military products at defense industry enterprises was $28.33 \%$, and $14.8 \%$ in 2018 .

- there is a low level of R\&D funding in the field of new equipment development (including insufficient funding from the Ministry of Economic Development and Trade of Ukraine to prepare the manufacturing process of new military equipment);

- in the defense sector, there is an intersection of $R \& D$ and serial production functions at the same enterprise, 
which sometimes either reduces the quality of research and development or increases the cost of production; - financial resources provided to enterprises by the state within the framework of their defense order (advance of the defense order - up to $80 \%$ of the cost of products for up to 3.5 years) are not allocated to separate accounting and in the general accounting of the enterprise is sometimes redistributed to other products).

Since 2015, the major markets for Ukrainian products have changed dramatically. Exports to Europe and America increased significantly. Due to the abandonment of the Russian market, exports to Asia and Africa have increased too (Table 4). Countries such as Turkey, Pakistan, Saudi Arabia, Qatar, etc. are also considered as a perspective markets.

Table 4. Exports of certain categories of Ukrainian weapons in the period 2014-2017, units

\begin{tabular}{|c|c|c|c|c|c|}
\hline \multirow{2}{*}{ Type of weapon } & \multicolumn{5}{|c|}{ Quantity and country of final consumer } \\
\hline & 2014 & 2015 & 2016 & 2017 & 2018 \\
\hline Battle tanks & $\begin{array}{l}11 \text { (Ethiopia), } \\
12 \text { (Nigeria) }\end{array}$ & $\begin{array}{l}4 \text { (Ethiopia), } \\
11 \text { (Nigeria), } \\
5 \text { (Thailand) }\end{array}$ & $\begin{array}{c}25 \text { (Democratic Republic } \\
\text { of the Congo), } \\
10 \text { (Thailand) }\end{array}$ & 16 (Thailand) & 13 (Thailand) \\
\hline $\begin{array}{c}\text { Armored combat } \\
\text { vehicles } \\
\end{array}$ & $\begin{array}{c}\text { (USA), } 17 \text { (Thailand), } \\
10 \text { (Nigeria) }\end{array}$ & 20 (Thailand) & $\begin{array}{c}34 \text { (Thailand), } \\
5 \text { (Indonesia), } 108 \text { (UAE) }\end{array}$ & - & 2 (Thailand) \\
\hline $\begin{array}{c}\text { Large caliber artillery } \\
\text { systems }\end{array}$ & 6 (Nigeria) & 12 (Nigeria) & - & - & - \\
\hline Fighter planes & 5 (Croatia), 1 (Chad) & - & - & - & - \\
\hline Combat helicopters & 6 (Belarus), 2 (Nigeria) & 5 (South Sudan) & - & - & - \\
\hline Warships & 1 (Китай) & - & - & - & - \\
\hline $\begin{array}{c}\text { Missiles and } \\
\text { rocket launchers }\end{array}$ & 18 (Algeria) & 2 (Indonesia) & $\begin{array}{c}3 \text { (Indonesia), } 40 \\
\text { (Poland) }\end{array}$ & - & $\begin{array}{c}\text { 9 Algeria, } \\
6 \text { Kazakhstan }\end{array}$ \\
\hline $\begin{array}{l}\text { Small arms: revolvers } \\
\text { and pistols }\end{array}$ & $\begin{array}{c}2 \text { (Democratic Republic } \\
\text { of the Congo), } 2 \\
\text { (Moldova), } \\
580 \text { (Peru) }\end{array}$ & $\begin{array}{l}2 \text { (UAE) } \\
4 \text { (Peru) }\end{array}$ & 4 (Turkey) & 1 (Jordan) & $\begin{array}{l}1 \text { USA, } \\
1 \text { Malaysia, } \\
200 \text { Turkey }\end{array}$ \\
\hline rifles and carbines & $\begin{array}{c}10166 \text { (USA), } \\
100 \text { (Georgia), } \\
10400 \text { (Canada), } \\
5000 \text { (Czech Republic), } \\
1 \text { (Democratic Republic } \\
\text { of the Congo), } 3000 \\
\text { (Uganda) }\end{array}$ & $\begin{array}{l}10000 \text { (USA), } \\
2544 \text { (Zambia) }\end{array}$ & $\begin{array}{l}10000 \text { (USA), } 10 \\
\text { (Mongolia) }\end{array}$ & 10 (Mongolia) & $\begin{array}{c}5068 \text { USA } 20 \\
\text { Mongolia }\end{array}$ \\
\hline assault rifles & $\begin{array}{c}2 \text { (Democratic Republic } \\
\text { of the Congo) }\end{array}$ & 104 (Zambia) & & & \\
\hline submachine guns & & & & $\begin{array}{c}15040 \\
\text { USA, } 2000 \\
\text { (Uzbekistan) }\end{array}$ & \\
\hline light machine guns & $\begin{array}{c}1 \text { (Democratic Republic } \\
\text { of the Congo), } \\
830 \text { (South Sudan) }\end{array}$ & 17 (Zambia) & $\begin{array}{c}\text { 46(Turkey), } \\
170 \text { (South Sudan) }\end{array}$ & & \\
\hline $\begin{array}{c}\text { Light weapons: } \\
\text { heavy machine guns }\end{array}$ & 62 (South Sudan) & - & 88 (South Sudan) & - & 177 USA \\
\hline $\begin{array}{c}\text { hand grenade } \\
\text { launchers }\end{array}$ & - & - & - & 2 (Jordan) & \\
\hline $\begin{array}{l}\text { portable rifles and } \\
\text { grenade launchers; }\end{array}$ & & $\begin{array}{l}89 \text { (USA), } 18 \\
\text { (Belarus) }\end{array}$ & & 790 (USA) & \\
\hline $\begin{array}{l}\text { portable missiles and } \\
\text { missile systems; }\end{array}$ & 1 (Belarus) & & 85 (USA) & 22 (Jordan) & $\begin{array}{l}950 \text { Saudi } \\
\text { Arabia }\end{array}$ \\
\hline triggers & 10 (Germany) & 3 (USA), 8 (UAE) & & 3 (Turkey) & \\
\hline missiles & & 226 (USA), 8 (UAE) & & & \\
\hline
\end{tabular}

Source: compiled by the author using the resource http://www.dsecu.gov.ua/control/en/index 
Although even after the change in the vector of foreign policy, the geography of Ukrainian exports coincides with areas of military conflict. This situation shapes the change in the structure of Ukrainian exports.

Ukrainian companies operate in the global arms market in the segment of aircraft construction, armored vehicles and ammunition. However, the presence in the markets of shipbuilding and air defense has recently been lost. Nowadays, Ukraine's role in world exports of defense products and services is significant not only due to the formation of its national and international security policy, foreign policy, but also due to the strengthening of arms control and export control regimes.

The problem of military products pricing is one of the most urgent in the process of ensuring the financial security of defense industry and the state in general, as in recent years financial resources for the development and purchase of modern defence equipment has significantly increased (Figure 1), and the range of products ordered in defense industry within the framework of the state order of Ukraine contains hundreds and thousands of names.

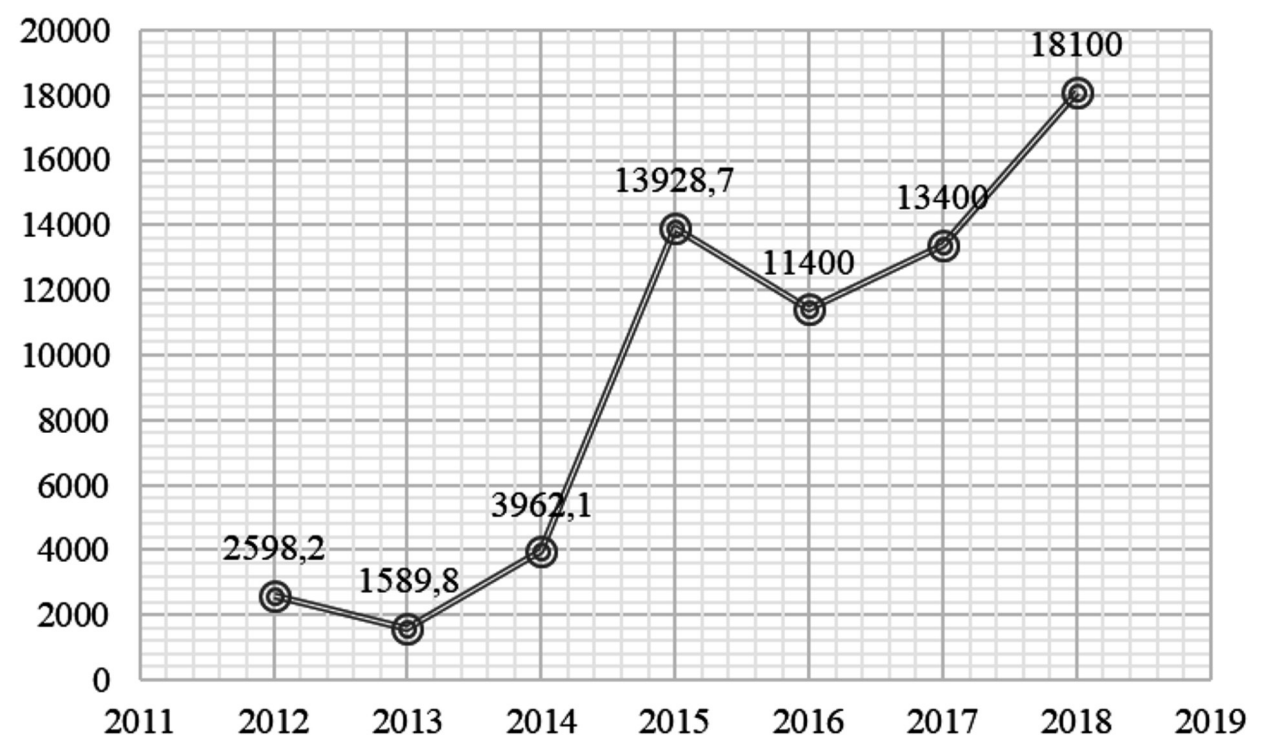

Figure 1. Expenditures for the development of armaments and military equipment of the Ministry of Defense of Ukraine, million UAH

Source: compiled by the author using the resource http://www.dsecu.gov.ua/control/en/index

In countries with developed market and mixed economies, the scope of state-regulated and controlled pricing makes from 10 to $40 \%$ of total output. For example, the share of state-controlled and regulated prices in Austria reaches $10 \%$, Germany - up to $40 \%$, Greece - 20\%, Denmark - 5\%, Spain - 10\%, Italy - up to 30\%, China - up to $30 \%$, USA - up to $10 \%$, France - $20 \%$, Finland - up to $40 \%$, Sweden - up to $40 \%$, Japan - up to $20 \%$ (Official website of the Department Of Homeland Security USA).

Analysis of regulatory documents on the regulation of public procurement, aimed at improving the objectivity and validity of pricing for MT shows that the existing pricing system for such products in Ukraine is based on the application of traditional method of calculation, which is quite expensive because it involves the summation of total costs and profits. Even the methods of calculating (forecasting) the cost of MT on the method of sampleanalogue are also costly, because they are based on data about the complexity and cost of previously performed work. This pricing system in Ukraine hinders the implementation of scientific, organizational, technological and other innovations in the defense industry, which should help reduce production costs and increase the level of enterprises` financial security. 
As a tool for subject-oriented financial security of defense industry enterprises, a value concept of pricing for defense industry products was proposed, which states that the price of products for the customer should be determined taking into account the value of sample products throughout the life cycle of its tactical and technical characteristics (quality, effect from application both in peacetime and in wartime, and also effect from possible application in other, non-military spheres of activity). The value concept of pricing allows to obtain a significant financial effect on the enterprise (e.g. the ability to save costs, increase the price of more innovative products, etc.).

\section{Discussion}

The conducted study on the operation of the DIC of Ukraine makes it possible to state that as of today legal framework for regulating the activities of DIC enterprises has already been developed in the country. This framework is presented by both legislative acts of general importance and special regulatory documents that directly define the legal status of DIC companies, the specifics of their activities in the field of national security and defense, strategic goals of reforming Ukroboronprom, etc.

At the same time, some problematic issues regarding the operation of the DIC of Ukraine remain unsolved and require special attention. In particular, they include the following: significant dependence on foreign suppliers; predominantly state ownership of enterprises in the structure of DIC; difficult access to credit and investment resources; weak domestic market of high-tech products; weak involvement in international cooperation; lack of management, human and financial resources for development, etc.

The solution of the problematic issues is seen as a possible way of introduction of leading technologies and the use of innovative equipment in the activities of DIC enterprises; development of mechanisms for financing the activities of DIC enterprises, including lending; developing mechanisms for stimulating innovation in the defense industry; intellectual property protection in accordance with international standards; cooperation with private sector companies and more.

\section{Conclusions}

The study provides a theoretical generalization and a new solution to the chosen scientific problem, which is manifested through the financial security of defense enterprises, taking into account the threats and opportunities for their interaction with the environment through the development of conceptual, methodological and applied components.

It was found that the existing inefficient and costly pricing system for MT products in Ukraine does not stimulate the implementation of organizational, technological, scientific and other innovations whithin defense enterprises, which in turn could reduce production costs and increase the financial security of enterprises.

The study identified ways to apply the value concept of pricing for MT products by defense companies, which minimizes the total cost of implementation of its entire life cycle during the development of MT and in turn encourages contractors to increase the competitiveness of the sample and eliminates price increases not associated with the quality improvement.

In Ukraine, the documents of the strategic planning for national security and defense protection were presented by the National Security Strategy of Ukraine 2015; Cybersecurity Strategy of Ukraine 2016; Strategy for the Development of the Defense Industrial Complex of Ukraine for the Period until 2028. The Ministry of Defense of Ukraine, the Ministry for Development of Economy, Trade and Agriculture of Ukraine and the state concern "Ukroboronprom", which activities are regulated by the provisions of the Statute, act as responsible bodies for production and transfer (supply, sale) of arms and military equipment. In 2018 the Strategy for Development of the Defense Industrial Complex of Ukraine for the period up to 2028 was developed. The Strategy is the basis for developing new and revising existing regulations in the area of development and operation of the 
DIC. Scientific support for exercise of authority in the field of national security of Ukraine by the President of Ukraine and the National Security and Defense Council of Ukraine is referred to the objectives of the National Institute for Strategic Studies established in 2012. The Central Scientific Research Institute of Armament and Military Equipment of Armed Forces of Ukraine (CSRI AME AF of Ukraine) is the main research institution of the Armed Forces of Ukraine engaged in the study of the problems of military-technical policy in the field of development of weapons and military equipment.

\section{References}

Arms production graphics (SIPRI Top 100). The official website of SIPRI. URL: https://www.sipri.org/research/armament-and-disarmament/arms-and-military-expenditure/arms-production

Avanesova, N.E., Kolodyazhna, T.V., \& Semenova, J.I. (2018). Strategic platform for economic developmentof enterprises of the military-industrial complex of Ukraine. Naukovyi visnyk Uzhhorodskoho natsionalnoho universytetu, 20(1), 6-9. URL: http://www. visnyk-econom.uzhnu.uz.ua/archive/20_1_2018ua/3.pdf

Behma, V.M., \& Sverhunov, O.O. (2019). Conceptual bases of the strategies of investment-innovative development of the defenseindustrial complexes of the states. Experience for Ukraine. Kyiv: NISD, 64p. URL: https://niss.gov.ua/sites/default/files/2019-07/Dopovid_Begma_druk.pdf

Export of military technology: who benefits from it? URL: http://myfin.net/ukraine/economy-and- finances-ua/eksport-voennyxtexnologij-komu-eto-vygodno-09125774.html

Kamianetska, O. (2015). Status and prospects of development of the military-industrial complex of Ukraine in the formation of national sovereignty. Visnyk Donetskoho natsionalnoho universytetu. Seriia V. Ekonomika i pravo, 1, 143-146. URL: http://jvestnik-c.donnu. edu.ua/article/view/291/302

Kravchenko, V. (2019). Military economics and military finance: new challenges in the first half of XXI century. Ekonomika ta derzhava, 9, 4-11. https://doi.org/10.32702/2306-6806.2019.9.4

Lonsdale, D.J. (2019). The 2018 Nuclear Posture Review: A return to nuclear warfighting? Comparative Strategy, 38, 98-117. https:// doi.org/10.1080/01495933.2019.1573074

Momot, T.V., Avanesova, N.E., \& Vinnik, I.U. (2015). The defense industry of Ukraine: priority directions of reform in the conditions of Eurointegration. Ekonomika i rehion, 5(54), 27-33.

Nzeribe, S., \& Imam, M. (2018). The military industrial complex: a catalyst for conflicts and wars (USA). Journal of Social Development, 7 (1), 73-81. https://doi.org/10.12816/0046772

Potomkina, M. (2018). Theoretical and legal foundations of economic legal relations in the defense industry of Ukraine. Part One. Pidpryiemnytstvo, hospodarstvo i pravo, 2, 58-62. URL: http://pgp-journal.kiev.ua/archive/2018/2/12.pdf

Qureshi, F.A. (2018). The Military Industrial Complex and its typology in the context of its political framework. International Journal of Political Science and Development, 6(5), 123-130. https://doi.org/10.14662/IJPSD2018.035

Resolution of the Cabinet of Ministers of Ukraine № 838 Issues of the Ministry of economy, trade and agriculture» (2019). As amended up to Act of December 24, 2019. URL: https://zakon.rada.gov.ua/laws/show/838-2019-\%D0\%BF

Resolution of the Cabinet of Ministers of Ukraine № 849 Some issues related to the activity of the State concern «Ukroboronprom» (2011). As amended up to Act of October 04, 2018. URL: https://zakon.rada.gov.ua/laws/show/849-2018-\%D0\%BF\#n6

Reznik O., Mazievich T., Shebanits D., Puzanova G., Pyrih I. (2020). Peculiarities of Ecological Taxation in Ukraine and the World. Journal of Legal, Ethical and Regulatory Issues 23(1), c. 1-6. URL: https://www.abacademies.org/articles/peculiarities-of-ecologicaltaxation-in-ukraine-and-the-world-9016.html

Official website of the Department Of Homeland Security USA. URL: https:/www.dhs.gov/cisa/defense-industrial-base-sector

On approval of the Strategy for the development of the defense-industrial complex of Ukraine for the period up to 2028. URL: https:// www.kmu.gov.ua/npas/pro-shvalennya-strategiyi-rozvitku-oboronno-promislovogo-kompleksu-ukrayini-na-period-do-2028-roku

State service of export control of Ukraine. URL: http://www.dsecu.gov.ua/control/en/index

Strategy for development of the defense-industrial complex of Ukraine for the period up to 2028 (2018). URL: https://zakon.rada.gov. 
ua/laws/show/442-2018-\%D1\%80

The official website of Central Research Institute of Weapons and Military Equipment. URL: https://cndiovt.com.ua

The official website of Ukroboronprom. URL: https://ukroboronprom.com.ua

Usachenko, O. (2019). Experience of state regulation of the reform of the US and EU defense industrial complex. Derzhavne upravlinnia: udoskonalennia ta rozvytok, 7. https://doi.org/10.32702/2307-2156-2019.7.24

Weber, R.N. (2020). Military-industrial complex. Encyclopædia Britannica. URL: https://www.britannica.com/topic/private-militaryfirm

\section{Oleksandr SYDOROV}

ORCID ID: orcid.org/0000-0002-4126-1894

Serhii TARASOV

ORCID ID: orcid.org/0000-0003-5518-4963

\section{Nelli TSYBULNYK}

ORCID ID: orcid.org/0000-0002-5128-0511

\section{Tetiana TSYBULNYK}

ORCID ID: orcid.org/0000-0002-1616-6844

\section{Anatolii RUSETSKYI}

ORCID ID: orcid.org/0000-0003-2234-4392 